Erschien zuerst in: Journal of Organometallic Chemistry 617-618 (2001) 464-472

\title{
Aminolysis of 3-alkoxysubstituted cyclobutenylidene complexes. A novel convenient route to chiral 3-aminosubstituted cyclobutenylidene complexes
}

\author{
Christoph C. Karl, Stefan Joneleit, Kerstin Weißenbach, Helmut Fischer* \\ Fachbereich Chemie, Universität Konstanz, Fach M727, D-78457, Konstanz, Germany
}

Received 2 August 2000; accepted 13 September 2000

\begin{abstract}
Aminolysis of 3-alkoxycyclobutenylidene complexes offers a convienient and high-yield route to a variety of 3-aminocyclobutenylidene complexes. Thus, the 3-diethylaminocyclobutenylidene complexes $\left[(\mathrm{CO})_{5} \mathrm{Cr}=\mathrm{C}\left(-\mathrm{C}(\mathrm{Me})=\mathrm{C}\left(\mathrm{NEt}_{2}\right)-\mathrm{CR}_{2}\right)\right][(\mathbf{4})$, $\mathrm{R}_{2}=\left(\mathrm{CH}_{2}\right)_{5}$ (a), $\mathrm{Me}_{2}$ (b), $\mathrm{Ph}_{2}$ (c)] are obtained by substitution of $\mathrm{NEt}_{2}$ of diethylamine for the ethoxy group in $\left[(\mathrm{CO})_{5} \mathrm{Cr}=\mathrm{C}\left(-\mathrm{C}(\mathrm{Me}) \mathrm{C}(\mathrm{OEt})-\mathrm{CR}_{2}\right)\right](\mathbf{3 a}-\mathbf{c})$. The reactions of $(R)-N$-methyl-1-phenylethyl amine and of $(S)$-2-methoxymethylpyrrolidine with $3 \mathbf{a}-\mathbf{c}$ afford the 3-N-methyl-(1-phenylethyl)amino- and 3-(2-methoxymethyl-pyrrolidino)-substituted cyclobutenylidene complexes, respectively, as mixtures of the $E$ and $Z$ isomers (with respect to the $\mathrm{C} 3-\mathrm{N}$ bond). Mixtures of the $E$ and $Z$ isomers of 3-(amino acid ester)-substituted cyclobutenylidene complexes are obtained from 3a,b and the methylester of L-leucine, L-phenylalanine, and L-methionine in yields ranging from 82 to $94 \%$. The $E / Z$ ratio strongly depends on the amino acid and the substituents at the sp ${ }^{3}-\mathrm{C}$ atom of the cyclobutenylidene ring. The reactions of $\mathbf{3 a}-\mathbf{c}$ with cysteine, $\mathrm{H}_{2} \mathrm{~N}-\mathrm{C}_{2} \mathrm{H}_{4}-\mathrm{SH}$, proceed highly selectively. Only 3-aminocyclobutenylidene complexes are isolated in 73-86\% yield. The formation of 3-organylthiocyclobutenylidene complexes has not been detected. The structure of the $E$-leucinyl methylester-substituted complex has been established by an X-ray structural analysis. (C) 2001 Elsevier Science B.V. All rights reserved.
\end{abstract}

Keywords: Cyclobutenylidene complexes; Aminolysis; Carbene complexes; Amino acids; Substitution

\section{Introduction}

Pentacarbonyl(vinylidene) complexes, $\left[(\mathrm{CO})_{5} \mathrm{M}=\right.$ $\mathrm{C}=\mathrm{CR}_{2}$ ], react with ynamines, $\mathrm{R}^{\prime}-\mathrm{C} \equiv \mathrm{C}-\mathrm{NR}_{2}^{\prime \prime}$, by cycloaddition of the $\mathrm{C}=\mathrm{C}$ bond to the $\mathrm{C}_{\alpha}-\mathrm{C}_{\beta}$ bond of the vinylidene ligand [1-3] (Scheme 1). The resulting 3aminosubstituted cyclobutenylidene complexes constitute organometallic push-pull systems in which a strong donor, $\mathrm{NR}_{2}^{\prime \prime}$, and the acceptor fragment $(\mathrm{CO})_{5} \mathrm{M}$ are connected by a four-membered cyclic $\pi$-system. Related homo- and heterobinuclear cyclobutenylidene complexes have been obtained by reaction of vinylidene complexes with alkynyl complexes [4-9]. The reactions of $\mathrm{MeC} \equiv \mathrm{CSMe}$ with $\left[(\mathrm{CO})_{5} \mathrm{Cr}=\mathrm{C}=\mathrm{CPh}_{2}\right][10]$ and of

\footnotetext{
* Corresponding author. Tel.: + 49-7531-882783; fax: +49-7531883136.

E-mail address: hfischer@dg6.chemie.uni-konstanz.de (H. Fischer).
}

$\mathrm{MeC} \equiv \mathrm{COEt} \quad$ with $\left[(\mathrm{CO})_{5} \mathrm{~W}=\mathrm{C}=\mathrm{CPh}_{2}\right] \quad[1]$ and $\left[(\mathrm{CO})_{5} \mathrm{Cr}=\mathrm{C}=\mathrm{C}\left(\mathrm{CH}_{2}\right)_{5}\right]$ [3] likewise afford cyclobutenylidene complexes.

From the spectra of 3-aminocyclobutenylidene complexes it follows that the dipolar resonance form II
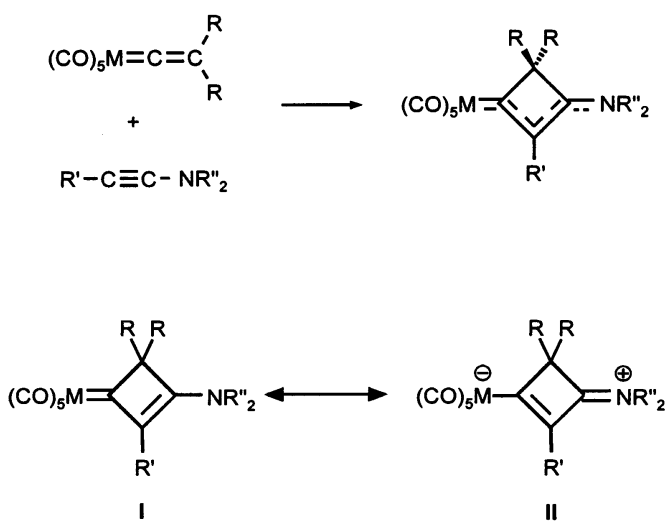

Scheme 1 


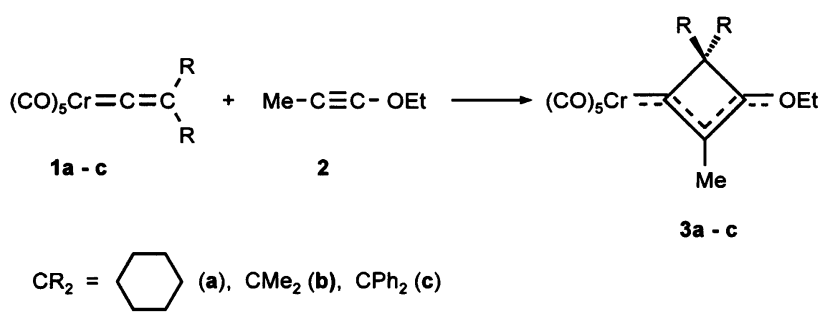

Scheme 2.

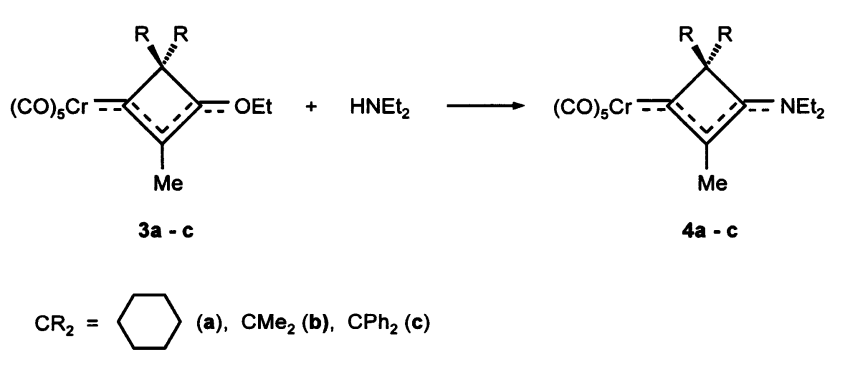

Scheme 3.

(Scheme 1) considerably contributes to the overall bonding situation.

In solution, these cyclobutenylidene complexes exhibit significant nonlinear optical properties. The first hyperpolarisabilities $\beta$ (SHG) as determined by hyperRayleigh scattering are similar to the $\beta$-value of $p$-nitroaniline. The observation of NLO effects on a macroscopic scale of solid samples requires that the compounds crystallize in an acentric space group. However, this precondition is not met by those cyclobutenylidene complexes where $\mathrm{NR}_{2}^{\prime \prime}$ is $\mathrm{NMe}_{2}, \mathrm{NEt}_{2}$, etc. The same applies to most other organometallic compounds. In general, more than $80 \%$ of organometallic compounds crystallize in a centric space group. The problem connected with crystallization in an acentric space group can in principle be circumvented by introducing a stereogenic center into the complex and by employing enantiomerically pure compounds. Following this reasoning we prepared the 3$(R)$-methyl(phenylethyl) amino-substituted and the 3-(S)-2-methoxymethyl-pyrrolidino-substituted cyclobutenylidene complexes (complexes $\mathbf{6 a}-\mathbf{c}$ and $\mathbf{8 a}-\mathbf{c}$, see Schemes 4 and 5, and determined their NLO response by the Kurtz powder method. In accordance with our assumption, crystalline samples of several of these complexes show considerable NLO effects. Unfortunately, the synthesis of the chiral ynamines required for the preparation of cyclobutenylidene complexes by the cycloaddition route is a multi-step, time-consuming process and affords the ynamines in rather low overall yields. We therefore searched for an alternative approach to 3-aminosubstituted cyclobutenylidene complexes.
Cyclobutenylidene complexes can be regarded as Fischer-type carbene complexes featuring a cyclic carbene ligand (see resonance form I, Scheme 1) with an electrophilic center at the $\mathrm{C} 3$ carbon atom (see resonance form II). Carbene complexes $\left[(\mathrm{CO})_{5} \mathrm{M}=\mathrm{C}(\mathrm{OR}) \mathrm{R}^{\prime}\right]$ 'react with ammonia, primary and secondary amines, $\mathrm{HNR}^{1} \mathrm{R}^{2}$, by substitution of the OR group to form aminocarbene complexes, $\left[(\mathrm{CO})_{5} \mathrm{M}=\mathrm{C}\left(\mathrm{NR}^{1} \mathrm{R}^{2}\right) \mathrm{R}^{\prime}\right]$ [11]. Transfer of this type of reactivity from carbene to cyclobutenylidene complexes should offer a convenient route to aminocyclo-butenylidene complexes.

\section{Results and discussion}

Previously, only two 2-alkoxy-substituted cyclobutenylidene complexes have been reported, a tungsten complex [3] and 3a [1]. Compound 3a was obtained by cycloaddition of 1-ethoxypropyne (2) to the vinylidene ligand of $\mathbf{1 a}$. The analogous reactions of $\mathbf{1 b}$ and $\mathbf{1 c}$ with 2 afford the 2-ethoxycyclobutenylidene(pentacarbonyl)chromium complexes $\mathbf{3 b}$ and $\mathbf{3 c}$ (Scheme 2).

The reaction rate strongly depends on the substituents at the $\mathrm{C}_{\beta}$ atom of the vinylidene complexes and increases in the series $\mathbf{1 c}<\mathbf{1 a}<\mathbf{1 b}$. The cycloaddition is accompanied by a shift of the $v(\mathrm{CO})$ absorptions of the pentacarbonyl fragment towards smaller wave numbers $\left(\Delta v=25-43 \mathrm{~cm}^{-1}\right)$ and of the resonance of the metal-bound $\mathrm{C}_{\alpha}$ towards higher field $(\Delta \delta=30-70$ ppm). These shifts indicate that addition of ethoxypropyne transforms the vinylidene ligand into a new ligand with significantly higher donor properties. When solutions of $\mathbf{3 a}-\mathbf{c}$ are cooled to $-80^{\circ} \mathrm{C}$ the resonances of the OEt substituent neither split nor broaden. Therefore the contribution of the dipolar resonance form (compare form II in Scheme 1) to the overal bonding description is small. The ${ }^{13} \mathrm{C}-\mathrm{NMR}$ resonance of the $\mathrm{C} 1$ (carbene) atom is between $\delta=330$ and $336 \mathrm{ppm}$ and is comparable to that of the carbene carbon atom in alkenyl(alkoxy)carbene complexes. The assignment of the $\mathrm{C} 2$ and the $\mathrm{C} 3$ atom of the ring has been established by $\mathrm{C}, \mathrm{H}$ correlation of $\mathrm{C} 3$ with $\mathrm{OCH}_{2}$ in the HMBC spectrum. The $\mathrm{C} 3$ atom in $\mathbf{3 b}, \mathbf{c}[\delta=186.0$ (3b) and $180.2(\mathbf{3 c})]$ is more deshielded than the $\mathrm{C} 2$ atom $[\delta=150.0(\mathbf{3 b})$ and $155.3(\mathbf{3 c})]$. From the $\mathrm{C} 3$ resonance at rather low field $(\delta=180.2-186.0)$ a COlike reactivity of $\mathrm{C} 3$ might be deduced.

In accordance with this conclusion, the cyclobutenylidene complexes $\mathbf{3 a}-\mathbf{c}$ rapidly react with diethylamine by substitution of the ethoxy group (Scheme 3). Even at $-40^{\circ} \mathrm{C}$, the reaction is complete within less than one minute. Products derived from addition of diethylamine to the $\mathrm{Cl}$ atom of $\mathbf{3 a}-\mathbf{c}$ are not observed.

The aminolysis is essentially quantitative, the isolated yields are between 93 and $96 \%$. The spectra of the complexes $4 \mathbf{a}-\mathbf{c}$ are identical with those prepared ear- 
lier by addition of 1-diethylaminopropyne to $\mathbf{1 a}-\mathbf{c}$. The $v(\mathrm{CO})$ absorptions appear at even smaller wave numbers than those of $\mathbf{3 a}-\mathbf{c}$ indicating an increase in electron donation from the cyclobutenylidene ligand to the $(\mathrm{CO})_{5} \mathrm{Cr}$ fragment. The ${ }^{1} \mathrm{H}-\mathrm{NMR}$ spectra of $\mathbf{4 a}-\mathbf{c}$ show two distinct sets of signals for the $\mathrm{NEt}_{2}$ protons. No line broadening is observed when solutions of $\mathbf{4 b}$ in toluene- $d_{8}$ are heated to $110^{\circ} \mathrm{C}$. From a detailed analysis of the ROESY spectrum of $\mathbf{4 b}$ a barrier for the rotation around the $\mathrm{C} 3-\mathrm{NEt}_{2}$ bond of $\Delta G^{\neq}=80 \pm 2 \mathrm{~kJ}$

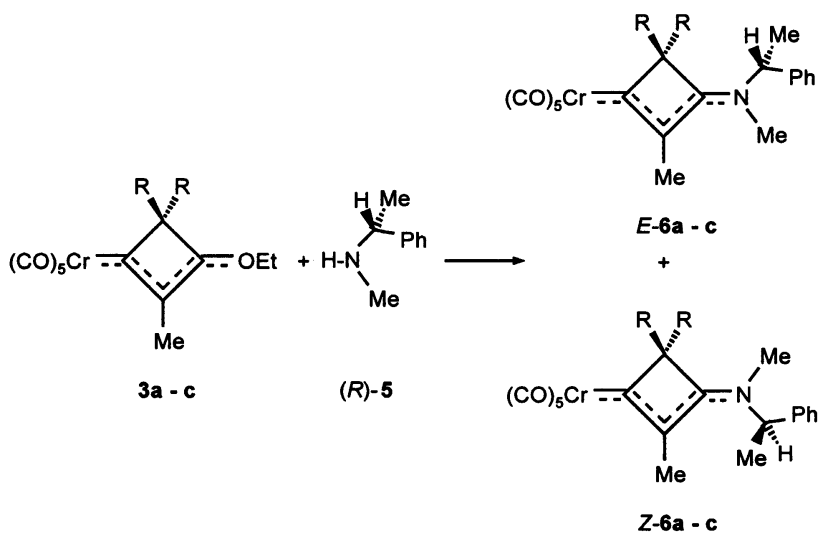

Scheme 4

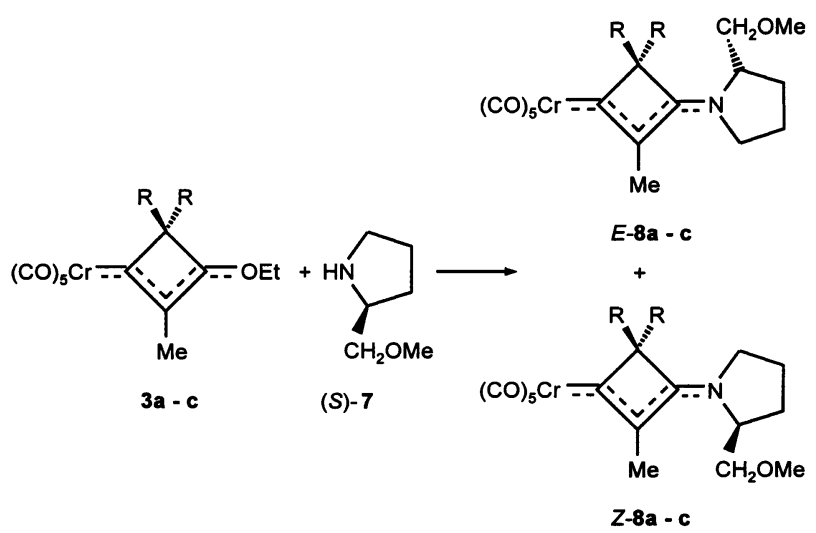

Scheme 5

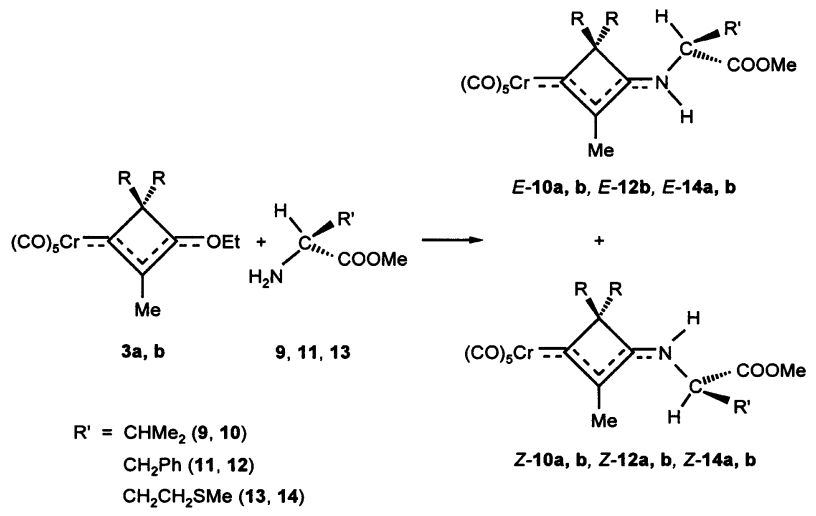

Scheme 6. $\mathrm{mol}^{-1}$ can be deduced in accordance with a significant contribution of the resonance form II to the overall bonding.

The reactions of $\mathbf{3 a}-\mathbf{c}$ with $(R)-N$-methyl-1phenylethyl amine $((R)-5)$ (Scheme 4) and (S)-2methoxymethyl-pyrrolidine ((S)-7) (Scheme 5), respectively, also proceed very fast and at $-40^{\circ} \mathrm{C}$ are complete within about $1 \mathrm{~min}$. After chromatography, the resulting complexes $6 \mathbf{a}-\mathbf{c}$ and $\mathbf{8 a}-\mathbf{c}$ are obtained in yields ranging from 75 to $93 \%$. This fast, high-yield aminolysis route offers considerable advantage over the alternative pathway involving cycloaddition of $(R)-1$ $N$-methyl-1-phenylethyl amino-1-propyne and $(S)$-2methoxymethyl-pyrrolidinopropyne to $\mathbf{1 a}-\mathbf{c}$ since it does not require the synthesis of chiral ynamines [3].

All complexes are isolated as mixtures of the $E$ and the $Z$ isomer. The $E / Z$ ratios $(E / Z=69: 31$ (6a), 57:43 (6b), 65:35 (6c), 15:85 (8a), 16:84 (8b) and 64:36 (8c)) agree very well with those of $\mathbf{6 a}-\mathbf{c}$ and $\mathbf{8 a}-\mathbf{c}$ prepared by reaction of the chiral ynamines with $1 \mathbf{a}-\mathbf{c}$ [3]. This indicates that these $E / Z$ ratios reflect the thermodynamic equilibrium and are not kinetically determined. Obviously, rotation around the $\mathrm{C} 3-\mathrm{N}$ bond is fast with respect to the preparative time scale.

The reactions of $\mathbf{3 a}, \mathbf{b}$ with the methyl esters of the amino acids L-valine (9), L-phenylalanine (11), and L-methionine (13) afford 3-amino acid ester-substituted cyclobutenylidene complexes in $82-94 \%$ yield (Scheme 6).

Complex 12a was isolated as the $Z$ isomer only. The formation of the $E$-12a could not be detected. All other complexes were obtained as mixtures of the $E$ and the $Z$ isomers (with respect to the $\mathrm{C} 3-\mathrm{N}$ partial double bond). The combined yields of the $E$ and $Z$ isomers range from 82 to $94 \%$. Analogously to $\mathbf{6 a}-\mathbf{c}$ and $\mathbf{8 a}-\mathbf{c}$, the $E$ and $Z$ isomers interconvert presumably by fast rotation around the $\mathrm{C} 3-\mathrm{N}$ bond. The $E / Z$ ratios therefore reflect the equilibrium distribution. In the cyclobutenylidene complexes derived from the dimethylvinylidene complex $\mathbf{3 b}$ the $E$ isomer dominates $[E / Z=2(\mathbf{1 0 b}), 3(\mathbf{1 2 b})$, the ratio for $\mathbf{1 4 b}$ could not exactly be determined]. Conversely, in the reaction of the cyclohexylvinylidene complex 3a with amino acid esters, predominantly the $Z$ isomer is formed $[E / Z=$ $0.56(\mathbf{1 0 a}), \approx 0$ (12a), 0.2 (14a)]. The UV-vis spectra are moderately solvent-dependent. The absorption at lowest energy assigned to a MLCT transition, shifts toward shorter wavelength when weakly polar solvents are replaced by more polar ones. The solvent-dependence of the amino acid ester-substituted cyclobutenylidene complexes is slightly more pronounced than that of the 3-amino-substituted complexes $\mathbf{6 a}, \mathbf{b}$ and $\mathbf{8 a}, \mathbf{b}$ (e.g. $\Delta v=1180 \mathrm{~cm}^{-1}$ (10a) and $862 \mathrm{~cm}^{-1}$ (8a) [3]).

From a mixture of $E / Z-10 b$ in pentane $/ \mathrm{CH}_{2} \mathrm{Cl}_{2}$ it was possible to grow a few crystals of diastereomerically pure $E$-10b suitable for an X-ray structural analy- 


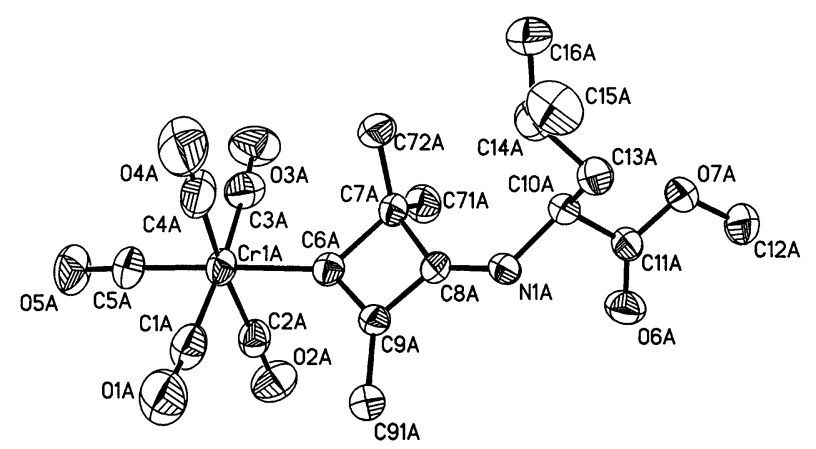

Fig. 1. Structure of molecule A of complex $E-\mathbf{1 0 b}$ (hydrogen atoms omitted for clarity).

sis. $E-\mathbf{1 0 b}$ crystallizes in the acentric space group $P 2_{1}$. The unit cell contains two independent molecules with slightly different bond length and angles. The structure of one molecule $[E-\mathbf{1 0 b}(\mathbf{A})]$ is shown in Fig. 1, selected bond length and angles are collected in Table 1.

The structure of $E-\mathbf{1 0 b}$ is similar to that of complex $Z$-6a [3]. The cyclobutenylidene ring is not planar but slightly puckered, the angle between the planes formed by the atoms $\mathrm{C}(6), \mathrm{C}(7), \mathrm{C}(9)$ and $\mathrm{C}(7), \mathrm{C}(8), \mathrm{C}(9)$ is $175.0^{\circ}$ in molecule $\mathrm{A}$ and $177.2^{\circ}$ in molecule B. Both $\mathrm{C}\left(\mathrm{sp}^{2}\right)-\mathrm{C}\left(\mathrm{sp}^{2}\right)$ distances $[\mathrm{C}(6)-\mathrm{C}(9)$ and $\mathrm{C}(8)-\mathrm{C}(9)]$ are almost equal in length, $\mathrm{C}(6)-\mathrm{C}(9)$ being slightly shorter than $\mathrm{C}(8)-\mathrm{C}(9)$. The $\mathrm{C}(8)-\mathrm{N}(1)$ distance is short [1.300(5) and 1.296(5) $\AA$ ], considerably shorter than that expected for a $\mathrm{C}\left(\mathrm{sp}^{2}\right)-\mathrm{N}\left(\mathrm{sp}^{2}\right)$ single bond $(1.355 \AA$ [12]). These bond distances indicate considerable $\pi$-interaction between the donor in 3-position (amino acid ester) and the $(\mathrm{CO})_{5} \mathrm{Cr}$ acceptor, in accordance with a significant shorter $\mathrm{Cr}-\mathrm{CO}($ trans $)$ bond compared with the mean value of the $\mathrm{Cr}-\mathrm{CO}(c i s)$ bonds $[1.877 \AA$ (molecule A) and $1.885 \AA$ (molecule B)]. From these structural parameters it follows that both resonance forms I and II (Scheme 1) contribute almost equally to the overall bonding. In agreement with the conclusion the $v(\mathrm{CO})$ vibrations of $\mathbf{1 0 a}, \mathbf{b}, \mathbf{1 2 a}, \mathbf{b}$, and $\mathbf{1 4 a}, \mathbf{b}$ are observed at rather low wave numbers.

The selectivity of the nucleophilic substitution at the 3-position of the cyclobutenylidene ring was investigated by use of the difunctional aminothiole cysteine (15). Even at $-40^{\circ} \mathrm{C}$ the complexes $3 \mathbf{a}-\mathbf{c}$ react in methanol with $\mathbf{1 5}$ within a few seconds to give the 3 -aminocyclobutenylidene complexes $\mathbf{1 6 a}-\mathbf{c}$ in $70-86 \%$ yield. There is no indication of the formation of the isomeric 3-organylthiocyclobutenylidene complex. The compounds $\mathbf{1 6 b}, \mathbf{c}$ are obtained as mixtures of the $E$ and $Z$ isomers. In contrast, only the $Z$ isomer of complex 16a is detected (Scheme 7).

The complexes 16a-c are thermally stable and can be kept in air for several weeks without decomposition. The $v(\mathrm{CO})$ absorptions at rather low wave numbers establish that $\mathbf{1 6 a}-\mathbf{c}$ are 3-aminocyclobutenylidene complexes. The $v(\mathrm{CO})$ absorptions of 3-organylthiocyclobutenylidene complex are usually observed at ca. $10-20 \mathrm{~cm}^{-1}$ higher wave numbers [3] due to the lower $\pi$-donor properties of the thio as compared to the amino group. The assignment of a 3-aminocyclobutenylidene structure to the complexes $\mathbf{1 6 a}-\mathbf{c}$ on the basis of the IR spectra is supported by the ${ }^{13} \mathrm{C}$ resonance of the chromium-bound $\mathrm{C}$ atom of the cyclobutenylidene ring in the range $\delta=297-304 \mathrm{ppm}$. The corresponding signal of 3-organylthiocyclobutenylidene complexes is expected at about $30 \mathrm{ppm}$ lower field.

Like amino acid ester-substituted cyclobutenylidene complexes, 16b and $\mathbf{1 6 c}$ are present in solution in the form of an $E / Z$ equilibrium. The $E / Z$ ratio as determined by integration of the NH resonance is 0.59 (16b) and 1.5 (16c). Analogously to other 3-aminocyclobutenylidene complexes the UV-vis spectra of $\mathbf{1 6 a}-$ c are solvent-dependent. The solvent-dependence is slightly more pronounced than that of 3-diethylaminocyclobutenylidene complexes [3].

In summary, the reaction of 3-alkoxy-substituted cyclobutenylidene complexes with amines offers a convenient route to a variety of aminocyclobutenylidene complexes. The yields are usually in the range $80-95 \%$. Chiral amines are easily introduced into the 3-position

Table 1

Selected bond lengths (pm) and angles $\left(^{\circ}\right)$ of complex $Z-\mathbf{1 0 b}$

\begin{tabular}{lrlr}
\hline Molecule A & \multicolumn{3}{l}{ Molecule B } \\
\hline Bond length & & & \\
Cr(1A)-C(5A) & $184.8(4)$ & $\mathrm{Cr}(1 \mathrm{~B})-\mathrm{C}(5 \mathrm{~B})$ & $185.8(5)$ \\
$\mathrm{Cr}(1 \mathrm{~A})-\mathrm{C}(6 \mathrm{~A})$ & $204.4(4)$ & $\mathrm{Cr}(1 \mathrm{~B})-\mathrm{C}(6 \mathrm{~B})$ & $205.0(4)$ \\
$\mathrm{C}(6 \mathrm{~A})-\mathrm{C}(7 \mathrm{~A})$ & $156.5(6)$ & $\mathrm{C}(6 \mathrm{~B})-\mathrm{C}(7 \mathrm{~B})$ & $156.6(6)$ \\
$\mathrm{C}(6 \mathrm{~A})-\mathrm{C}(9 \mathrm{~A})$ & $139.0(6)$ & $\mathrm{C}(6 \mathrm{~B})-\mathrm{C}(9 \mathrm{~B})$ & $138.2(6)$ \\
$\mathrm{C}(7 \mathrm{~A})-\mathrm{C}(8 \mathrm{~A})$ & $151.5(6)$ & $\mathrm{C}(7 \mathrm{~B})-\mathrm{C}(8 \mathrm{~B})$ & $151.8(6)$ \\
$\mathrm{C}(7 \mathrm{~A})-\mathrm{C}(71 \mathrm{~A})$ & $151.7(7)$ & $\mathrm{C}(7 \mathrm{~B})-\mathrm{C}(71 \mathrm{~B})$ & $150.9(8)$ \\
$\mathrm{C}(7 \mathrm{~A})-\mathrm{C}(72 \mathrm{~A})$ & $152.5(6)$ & $\mathrm{C}(7 \mathrm{~B})-\mathrm{C}(72 \mathrm{~B})$ & $152.1(6)$ \\
$\mathrm{C}(8 \mathrm{~A})-\mathrm{N}(1 \mathrm{~A})$ & $130.0(5)$ & $\mathrm{C}(8 \mathrm{~B})-\mathrm{N}(1 \mathrm{~B})$ & $129.6(5)$ \\
$\mathrm{C}(8 \mathrm{~A})-\mathrm{C}(9 \mathrm{~A})$ & $139.8(6)$ & $\mathrm{C}(8 \mathrm{~B})-\mathrm{C}(9 \mathrm{~B})$ & $139.8(6)$ \\
$\mathrm{C}(9 \mathrm{~A})-\mathrm{C}(91 \mathrm{~A})$ & $149.0(6)$ & $\mathrm{C}(9 \mathrm{~B})-\mathrm{C}(91 \mathrm{~B})$ & $148.2(6)$ \\
$\mathrm{N}(1 \mathrm{~A})-\mathrm{C}(10 \mathrm{~A})$ & $144.7(6)$ & $\mathrm{N}(1 \mathrm{~B})-\mathrm{C}(10 \mathrm{~B})$ & $144.7(6)$ \\
Bond angles & & & \\
$\mathrm{C}(1 \mathrm{~A})-\mathrm{Cr}(1 \mathrm{~A})-\mathrm{C}(6 \mathrm{~A})$ & $92.0(2)$ & $\mathrm{C}(1 \mathrm{~B})-\mathrm{Cr}(1 \mathrm{~B})-\mathrm{C}(6 \mathrm{~B})$ & $86.6(2)$ \\
$\mathrm{C}(2 \mathrm{~A})-\mathrm{Cr}(1 \mathrm{~A})-\mathrm{C}(6 \mathrm{~A})$ & $85.6(2)$ & $\mathrm{C}(2 \mathrm{~B})-\mathrm{Cr}(1 \mathrm{~B})-\mathrm{C}(6 \mathrm{~B})$ & $92.7(2)$ \\
$\mathrm{C}(3 \mathrm{~A})-\mathrm{Cr}(1 \mathrm{~A})-\mathrm{C}(6 \mathrm{~A})$ & $91.9(2)$ & $\mathrm{C}(3 \mathrm{~B})-\mathrm{Cr}(1 \mathrm{~B})-\mathrm{C}(6 \mathrm{~B})$ & $87.2(2)$ \\
$\mathrm{C}(4 \mathrm{~A})-\mathrm{Cr}(1 \mathrm{~A})-\mathrm{C}(6 \mathrm{~A})$ & $86.9(2)$ & $\mathrm{C}(4 \mathrm{~B})-\mathrm{Cr}(1 \mathrm{~B})-\mathrm{C}(6 \mathrm{~B})$ & $94.0(2)$ \\
$\mathrm{C}(9 \mathrm{~A})-\mathrm{C}(6 \mathrm{~A})-\mathrm{C}(7 \mathrm{~A})$ & $91.4(3)$ & $\mathrm{C}(9 \mathrm{~B})-\mathrm{C}(6 \mathrm{~B})-\mathrm{C}(7 \mathrm{~B})$ & $91.6(3)$ \\
$\mathrm{C}(9 \mathrm{~A})-\mathrm{C}(6 \mathrm{~A})-\mathrm{Cr}(1 \mathrm{~A})$ & $136.6(4)$ & $\mathrm{C}(9 \mathrm{~B})-\mathrm{C}(6 \mathrm{~B})-\mathrm{Cr}(1 \mathrm{~B})$ & $137.4(3)$ \\
$\mathrm{C}(7 \mathrm{~A})-\mathrm{C}(6 \mathrm{~A})-\mathrm{Cr}(1 \mathrm{~A})$ & $131.9(3)$ & $\mathrm{C}(7 \mathrm{~B})-\mathrm{C}(6 \mathrm{~B})-\mathrm{Cr}(1 \mathrm{~B})$ & $130.9(3)$ \\
$\mathrm{C}(8 \mathrm{~A})-\mathrm{C}(7 \mathrm{~A})-\mathrm{C}(6 \mathrm{~A})$ & $82.1(3)$ & $\mathrm{C}(8 \mathrm{~B})-\mathrm{C}(7 \mathrm{~B})-\mathrm{C}(6 \mathrm{~B})$ & $82.0(3)$ \\
$\mathrm{N}(1 \mathrm{~A})-\mathrm{C}(8 \mathrm{~A})-\mathrm{C}(9 \mathrm{~A})$ & $132.9(5)$ & $\mathrm{N}(1 \mathrm{~B})-\mathrm{C}(8 \mathrm{~B})-\mathrm{C}(9 \mathrm{~B})$ & $133.7(4)$ \\
$\mathrm{N}(1 \mathrm{~A})-\mathrm{C}(8 \mathrm{~A})-\mathrm{C}(7 \mathrm{~A})$ & $133.8(4)$ & $\mathrm{N}(1 \mathrm{~B})-\mathrm{C}(8 \mathrm{~B})-\mathrm{C}(7 \mathrm{~B})$ & $133.2(4)$ \\
$\mathrm{C}(9 \mathrm{~A})-\mathrm{C}(8 \mathrm{~A})-\mathrm{C}(7 \mathrm{~A})$ & $93.2(3)$ & $\mathrm{C}(9 \mathrm{~B})-\mathrm{C}(8 \mathrm{~B})-\mathrm{C}(7 \mathrm{~B})$ & $93.0(3)$ \\
$\mathrm{C}(6 \mathrm{~A})-\mathrm{C}(9 \mathrm{~A})-\mathrm{C}(8 \mathrm{~A})$ & $93.1(4)$ & $\mathrm{C}(6 \mathrm{~B})-\mathrm{C}(9 \mathrm{~B})-\mathrm{C}(8 \mathrm{~B})$ & $93.3(4)$ \\
$\mathrm{C}(6 \mathrm{~A})-\mathrm{C}(9 \mathrm{~A})-\mathrm{C}(91 \mathrm{~A})$ & $136.3(4)$ & $\mathrm{C}(6 \mathrm{~B})-\mathrm{C}(9 \mathrm{~B})-\mathrm{C}(91 \mathrm{~B})$ & $135.7(4)$ \\
$\mathrm{C}(8 \mathrm{~A})-\mathrm{C}(9 \mathrm{~A})-\mathrm{C}(91 \mathrm{~A})$ & $130.6(4)$ & $\mathrm{C}(8 \mathrm{~B})-\mathrm{C}(9 \mathrm{~B})-\mathrm{C}(91 \mathrm{~B})$ & $130.9(4)$ \\
& & &
\end{tabular}




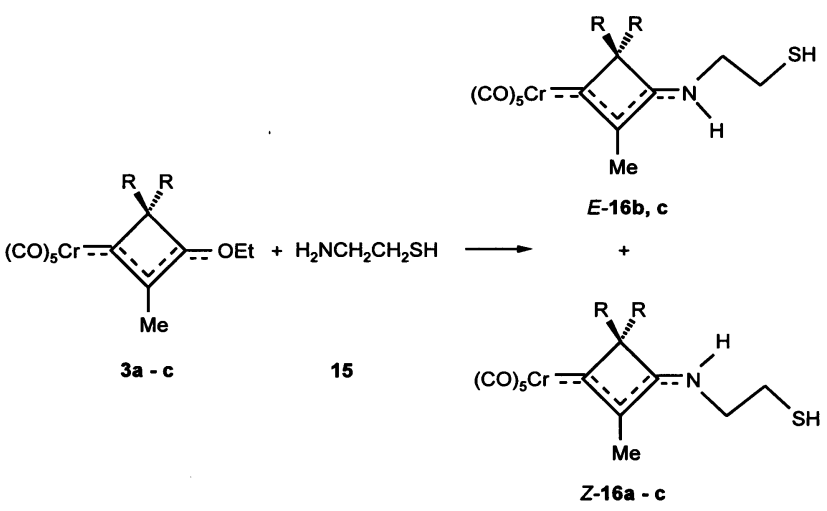

Scheme 7.

of the cyclobutenylidene ring by employing the corresponding amines from the chiral pool. Thus, the very time-consuming synthesis of chiral ynamines connected with low overall yields can be avoided. Although usually $E / Z$ equilibrium mixtures are obtained it is possible to shift the equilibrium completely towards one isomer by choosing suitable amino-substituents $\mathrm{N}(\mathrm{H}) \mathrm{R}$.

\section{Experimental}

\subsection{General}

All operations were performed under an inert atmosphere (nitrogen or argon) by using standard Schlenk techniques. Solvents were dried by refluxing over $\mathrm{CaH}_{2}$ $\left(\mathrm{CH}_{2} \mathrm{Cl}_{2}\right.$, pentane) or sodium/benzophenone ketyl $\left(\mathrm{Et}_{2} \mathrm{O}\right)$ and were freshly distilled under argon prior to use. The silica gel used for chromatography (Baker, silica gel for flash chromatography) was nitrogen saturated. The yields refer to analytically pure compounds and were not optimized. Instrumentation: ${ }^{1} \mathrm{H}$ - and ${ }^{13} \mathrm{C}$ NMR spectra were recorded with a Bruker AC 250, a Bruker WM 250 or a Bruker DRX600 spectrometer. If not specifically mentioned ${ }^{1} \mathrm{H}-\mathrm{NMR}$ and ${ }^{13} \mathrm{C}$-NMR resonances are reported relative to the residual solvent peaks of $\mathrm{CDCl}_{3}$ or $\mathrm{CD}_{2} \mathrm{Cl}_{2}$. Unless specified, IR and NMR spectra are taken at room temperature (r.t.). IR: Biorad FTS 60 spectrophotometer; MS: Finnigan MAT 312 (EI, $70 \mathrm{eV}$ ). Elemental analyses: Heraeus CHN-ORAPID. The vinylidene complexes 1a [10], 1b [1], 1c [9], the 3-ethoxy-cyclobut-2-en-1-ylidene complexes 3a [3], the alkyne 2 [13] and the amines $(R)-5$ [14] and $(S)-7$ [15] were prepared according to literature procedures. All other compounds were commercially available and were used without further purification.

\subsection{Synthesis of the 3-ethoxy-cyclobut-2-en-1-ylidene complexes $\mathbf{3 b}$ and $\mathbf{3} \boldsymbol{c}$}

At $-80^{\circ} \mathrm{C}, 2(15.5 \mathrm{mmol}, 1.33 \mathrm{ml})$ is added to a solution of $10.2 \mathrm{mmol}$ of $\mathbf{1 b}(\mathbf{1 c})$ in $84 \mathrm{ml}(40 \mathrm{ml})$ of $\mathrm{CH}_{2} \mathrm{Cl}_{2}$. After stirring for $10 \mathrm{~min}$ the solution is allowed to warm to r.t. within $45 \mathrm{~min}$ (about $12 \mathrm{~h}$ ). The color of the solution turns red. The solvent is removed in vacuo. The residue is dissolved at $-30^{\circ} \mathrm{C}$ in $100 \mathrm{ml}$ of pentane and chromatographed on silica. With pentane-dichloromethane first a slightly yellow band $\left(\mathrm{Cr}(\mathrm{CO})_{6}\right)$ and subsequently a red band is eluted. The red band is collected. The solvent is removed in vacuo and the residue is recrystallized from $12 \mathrm{ml}$ of pentane.

\subsubsection{Pentacarbonyl[3-ethoxy-2,4,4-trimethylcyclobut- 2-en-1-ylidene]chromium (3b)}

Chromatography with 9:1 pentane-dichloromethane. Slightly red needles. Yield: $0.19 \mathrm{~g}(0.64 \mathrm{mmol} ; 8 \%$ relative to 1b). M.p. $28^{\circ} \mathrm{C}$. IR (pentane) $v(\mathrm{CO})\left(\mathrm{cm}^{-1}\right)$ : $2054 \mathrm{~m}, 1976 \mathrm{w}, 1950$ vs, 1933 s. ${ }^{1} \mathrm{H}-\mathrm{NMR}\left(\mathrm{CD}_{2} \mathrm{Cl}_{2}\right.$, $263 \mathrm{~K}, 250 \mathrm{MHz}): \delta 1.34$ (s, 6H, 4- $\left.\mathrm{CH}_{3}\right), 1.48$ (t, $J=7.0$ $\left.\mathrm{Hz}, 3 \mathrm{H}, \mathrm{CH}_{2} \mathrm{CH}_{3}\right), 2.20\left(\mathrm{~s}, 3 \mathrm{H}, 2-\mathrm{CH}_{3}\right), 4.40(\mathrm{q}, J=7.0$ $\left.\mathrm{Hz}, 2 \mathrm{H}, \mathrm{CH}_{2} \mathrm{CH}_{3}\right) .{ }^{13} \mathrm{C}-\mathrm{NMR}\left(\mathrm{CD}_{2} \mathrm{Cl}_{2}, 263 \mathrm{~K}, 62.5\right.$ $\mathrm{MHz}): \delta 12.8\left(2-\mathrm{CH}_{3}\right), 15.0\left(\mathrm{CH}_{2} \mathrm{CH}_{3}\right) 23.6\left(4-\mathrm{CH}_{3}\right)$, 63.4 (C4), 150.0 (C2), 186.0 (C3), 217.7 (cis-CO), 227.4 (trans-CO), $335.9(\mathrm{C} 1)$. UV-vis $\left(\lambda_{\max }, \mathrm{nm}(\log \varepsilon)\right.$ [solvent]): $442 \mathrm{~nm}$ (4.233) [pentane], $422 \mathrm{~nm}$ (4.123) [DMF]. MS $m / z(\%): 330(9)\left[\mathrm{M}^{+}\right], 302(1)\left[\mathrm{M}^{+}-\mathrm{CO}\right]$, 274(5) $\left[\mathrm{M}^{+}-2 \mathrm{CO}\right], 246(4)\left[\mathrm{M}^{+}-3 \mathrm{CO}\right], 218(17)\left[\mathrm{M}^{+}\right.$ $-4 \mathrm{CO}], 190(84)\left[\mathrm{M}^{+}-5 \mathrm{CO}\right], 52(100)\left[\mathrm{Cr}^{+}\right]$. Anal. Found: C, 50.66; H, 4.25. $\mathrm{C}_{14} \mathrm{H}_{14} \mathrm{CrO}_{6}(330.0)$. Calc.: $\mathrm{C}$, $50.91 ; \mathrm{H}, 4.28 \%$.

\subsubsection{Pentacarbonyl[3-ethoxy-2-methyl-4,4-}

diphenylcyclobut-2-en-1-ylidene]chromium (3c)

Chromatography with pentane-dichloromethane (ratio decreasing from 1:0 to 3:2). Orange platelets. Yield: $0.73 \mathrm{~g}(1.6 \mathrm{mmol} ; 16 \%$ relative to $1 \mathrm{c})$. M.p. $76^{\circ} \mathrm{C}$ (dec.). IR (pentane): $v(\mathrm{CO})\left(\mathrm{cm}^{-1}\right): 2054 \mathrm{~m}, 1950 \mathrm{vs}, 1939 \mathrm{~s}$. ${ }^{1} \mathrm{H}-\mathrm{NMR}\left(\mathrm{CD}_{2} \mathrm{Cl}_{2}, 263 \mathrm{~K}, 250 \mathrm{MHz}\right): \delta 1.22(\mathrm{t}, J=7.1$ $\left.\mathrm{Hz}, 3 \mathrm{H}, \mathrm{CH}_{2} \mathrm{CH}_{3}\right), 2.37$ (s, 3H, 2- $\left.\mathrm{CH}_{3}\right), 4.22$ (q, $J=7.1$ $\left.\mathrm{Hz}, 2 \mathrm{H}, \mathrm{CH}_{2} \mathrm{CH}_{3}\right), 7.33-7.43(\mathrm{~m}, 10 \mathrm{H}, \mathrm{Ph}) .{ }^{13} \mathrm{C}-\mathrm{NMR}$ $\left(\mathrm{CDCl}_{3}, 263 \mathrm{~K}, 62.5 \mathrm{MHz}\right): \delta 12.2\left(2-\mathrm{CH}_{3}\right), 14.7$ $\left(\mathrm{CH}_{2} \mathrm{CH}_{3}\right) 68.6\left(\mathrm{OCH}_{2}\right), 77.2(\mathrm{C} 4), 127.7,128.5,129.1$, $139.7(\mathrm{Ph}), 155.3(\mathrm{C} 2), 180.2(\mathrm{C} 3), 216.8$ (cis-CO), 226.9 (trans-CO), $332.4(\mathrm{C} 1)$. UV-vis $\left(\lambda_{\max }, \mathrm{nm}(\log \varepsilon)\right.$ [solvent]): $464 \mathrm{~nm}$ (4.269) [pentane], $444 \mathrm{~nm}$ (4.198) [DMF]. MS $m / z(\%): 454(4)\left[\mathrm{M}^{+}\right], 398(1)\left[\mathrm{M}^{+}-2 \mathrm{CO}\right.$, 370(4) $\left[\mathrm{M}^{+}-3 \mathrm{CO}\right], 342(5)\left[\mathrm{M}^{+}-4 \mathrm{CO}\right], 314(44)\left[\mathrm{M}^{+}\right.$ $-5 \mathrm{CO}], 262(100)\left[\mathrm{M}^{+}-5 \mathrm{CO}-\mathrm{Cr}\right], 234(85)\left[\mathrm{M}^{+}-\right.$ $5 \mathrm{CO}-\mathrm{Cr}-\mathrm{C}_{2} \mathrm{H}_{4}$ ]. Anal. Found: $\mathrm{C}, 63.52 ; \mathrm{H}, 4.07$. $\mathrm{C}_{24} \mathrm{H}_{18} \mathrm{CrO}_{6}$ (454.1). Calc.: C, 63.43; H, 4.00\%. 
3.3. Pentacarbonyl[(3-diethylamino-2-methyl)spiro[5.3]non-2-en-1-ylidene]chromium (4a), pentacarbonyl[(3-diethylamino-2,4,4-trimethyl)cyclobut-2-en-1-yliene]chromium (4b), and pentacarbonyl[(3-diethylamino-2-methyl-4,4-diphenyl)cyclobut-2-en-1-ylidene]chromium (4c)

At $-40^{\circ} \mathrm{C}$, cold diethylamine $(4.8 \mathrm{mmol}, 0.5 \mathrm{ml})$ is added to $0.25 \mathrm{mmol}$ of $\mathbf{3}$ (3a: $95 \mathrm{mg}$; $\mathbf{3 b}$ : $85 \mathrm{mg}$; $\mathbf{3 c}$ : $115 \mathrm{mg}$ ). The color immediately changes from orange to yellow. The reaction is complete within ca. $1 \mathrm{~min}$. as determined by IR spectroscopy. Excess diethylamine is removed in vacuo at r.t. The residue is extracted with $10 \mathrm{ml}$ of pentane, decanted and dried in vacuo. The complexes $\mathbf{4 a}-\mathbf{c}$ are obtained as yellow $(\mathbf{4 a}, \mathbf{b})$ and orange powders (4c) and identified by comparison of their IR and NMR spectra with those of authentic samples. Yield: 4a: $100 \mathrm{mg}(0.24 \mathrm{mmol}$; 93\% relative to $3 \mathbf{a})$. $\mathbf{4 b}$ : $95 \mathrm{mg}(0.24 \mathrm{mmol} ; 93 \%$ relative to $3 \mathbf{a})$. $4 \mathbf{b}: 115 \mathrm{mg}(0.24 \mathrm{mmol} ; 96 \%$ relative to 3c).

\subsection{Pentacarbonyl[(2-methyl-3-\{methyl-(R)-}

(1-phenylethyl)amino -spiro[5.3]non-2-en-1-ylidene]chromium $(E / Z-(R)-6 a)$, pentacarbonyl[3-\{N-methyl(R)-(1-phenylethyl)amino $\}$-2,4,4-dimethyl-cyclobut2-en-1-ylidene $]$ chromium $(E / Z-(R)-\boldsymbol{\sigma b})$, and pentacarbonyl[2-methyl-3-\{methyl-(R)-(1-phenylethyl)amino\}-4,4-diphenyl-cyclobut-2-en-1-ylidene]chromium $(E / Z(R)-\boldsymbol{\sigma c})$

At $\quad-40^{\circ} \mathrm{C}, \quad$ a solution of $(R)-N$-methyl-(1phenylethyl)amine $((R)-5)(0.40 \mathrm{mmol}, 54 \mathrm{mg})$ in one $\mathrm{ml}$ of methanol is added to a solution of $0.25 \mathrm{mmol}$ of $\mathbf{3}(95 \mathrm{mg} \mathrm{3a}, 85 \mathrm{mg} \mathrm{3b}, 115 \mathrm{mg} \mathrm{3c})$ in $4.5 \mathrm{ml}$ of methanol. Within $1 \mathrm{~min}$, the color of the solution changes from orange to yellow. After stirring the solution for $30 \mathrm{~min}$ at $-45^{\circ} \mathrm{C}$ the solvent is removed in vacuo. The yellow residue is dissolved in $10 \mathrm{ml}$ of 1:1 pentane-dichloromethane and chromatographed at $-35^{\circ} \mathrm{C}$ with pentane-dichloromethane on silica (ratio decreasing from $2: 1$ to $1: 1$ ). A yellow band is eluted. The solvent is removed in vacuo to afford $E / Z$ - $(S)$-6a as a yellow powder, $E / Z-(S)-\mathbf{6 b}$ as a yellow highly viscous oil and $E / Z-(S)-6 c$ as an orange powder. The complexes are identified by comparison of their IR and NMR spectra with those of authentic samples. Yield: $E / Z-(R)-6 a$ : $83 \mathrm{mg}(0.20 \mathrm{mmol} ; 81 \%$ relative to 3a); $E / Z-(R)-6 \mathbf{b}: 84 \mathrm{mg}(0.23 \mathrm{mmol} ; 93 \%$ relative to $3 \mathbf{b}) ; E / Z$ - $(S)-6 \mathbf{c}: 110 \mathrm{mg}(0.21 \mathrm{mmol} ; 83 \%$ relative to $\mathbf{3 c}$ ).
3.5. Pentacarbonyl[3-((S)-2-methoxymethylpyrrolidino $)-$ 2-methyl-spiro[5.3]non-2-en-1-ylidene]chromium (E/Z-(S)-8a), pentacarbonyl[3-((S)-2-methoxymethylpyrrolidino)-2,4,4-trimethyl-cyclobut-2en-1-ylidene $]$ chromium $(E / Z-(S)-8 b)$, and pentacarbonyl[3-((S)-2-methoxymethylpyrrolidino)2-methyl-4,4-diphenyl-cyclobut-2-en-1-ylidene]chromium $(E / Z-(S)-8 c)$

The reaction of of $(S)-(+)$-2-methoxymethyl-pyrrolidine $((S)-7)(0.40 \mathrm{mmol}, 45 \mathrm{mg})$ with $0.25 \mathrm{mmol}$ of 3 (95 mg 3a, $85 \mathrm{mg} \mathrm{3b}, 115 \mathrm{mg} \mathrm{3c})$ and the chromatography are carried out analogously to Section 3.4. As the eluent, pentane-dichloromethane-diethyl ether (ratio decreasing from $1: 1: 0$ to $1: 3: 1$ ) is used. $E / Z-(S)-8 \mathrm{a}$ is obtained as a yellow powder, $E / Z-(S)$ 8b as a yellow highly viscous oil and $E / Z-(S)-8 c$ as an orange powder. The complexes are identified by comparison of their IR and NMR spectra with those of authentic samples. Yield: $E / Z-(S)-8 \mathbf{a}: 83 \mathrm{mg}(0.29$ $\mathrm{mmol} ; 75 \%$ relative to $3 \mathbf{3 a}) ; E / Z-(S)-8 \mathbf{b}: 84 \mathrm{mg}(0.21$ mmol; $86 \%$ relative to $3 \mathbf{b}) ; E / Z-(S)-8 \mathbf{c}: 115 \mathrm{mg}(0.22$ mmol; $89 \%$ relative to $3 \mathbf{c}$ ).

\subsection{Reaction of $\mathbf{3 a}$ and $\mathbf{3 b}$ with amino acid methylesters}

A solution of $4 \mathrm{mmol}$ of the corresponding Lamino acid methylester (Leu, Phe, Met) in $4 \mathrm{ml}$ of dry methanol is added at $-40^{\circ} \mathrm{C}$ to a solution of 0.6 $\mathrm{mmol}$ of $\mathbf{3 a}$ and $\mathbf{3 b}$, respectively, in $10 \mathrm{ml}$ of dry methanol. After $15 \mathrm{~min}$, the solution is allowed to warm to r.t. and stirred for $30 \mathrm{~min}$. The color of the solution changes from orange to yellow. The solvent is removed in vacuo. The oily brown-yellow residue is dissolved in a few $\mathrm{ml}$ of $\mathrm{CH}_{2} \mathrm{Cl}_{2}$ and chromatographed at $-20^{\circ} \mathrm{C}$ on silica. First, excess ester and $\mathrm{Cr}(\mathrm{CO})_{6}$ are eluted with 9:1 pentane- $\mathrm{CH}_{2} \mathrm{Cl}_{2}$ and then the product complex with 9:1 $\mathrm{CHCl}_{3}-\mathrm{MeOH}$ and 1:1 $\mathrm{CHCl}_{3}$-THF. The solvent is removed in vacuo and the solid complexes (10a,b and 12a,b) are recrystallized from pentane $/ \mathrm{CH}_{2} \mathrm{Cl}_{2}$. The methionine methylester derivatives $\mathbf{1 4 a}, \mathbf{b}$ are obtained as oils.

\subsubsection{Pentacarbonyl(3- $N$-(S)-leucinyl}

methylester-2-methyl-spiro[3.5]cyclobut-2-en-1-ylidene)chromium (10a)

Yellow crystals. Yield $0.27 \mathrm{~g}$ (94\% relative to 3a). M.p. $104^{\circ} \mathrm{C}$. IR $\left(\mathrm{CH}_{2} \mathrm{Cl}_{2}\right) v(\mathrm{CO})\left(\mathrm{cm}^{-1}\right): 2044 \mathrm{~m}, 1960$ vw, 1923 vs, 1917 s. ${ }^{1} \mathrm{H}-\mathrm{NMR}\left(\mathrm{CDCl}_{3}, 250 \mathrm{MHz}\right.$, TMS): $\delta 0.83-0.94\left(\mathrm{~m}, 8 \mathrm{H}, \mathrm{CH}_{2},{ }^{i} \mathrm{Pr}-\mathrm{CH}_{3}\right), 1.05-1.55$, $1.56-1.80,1.85-2.00\left(\mathrm{~m}, 10 \mathrm{H}, \mathrm{CH}_{2}\right), 2.07(\mathrm{~s}, 3 \mathrm{H}$, $\left.\mathrm{C} 2-\mathrm{CH}_{3}\right), \quad 3.39-3.48\left(\mathrm{~m}, 1 \mathrm{H}, \mathrm{CH}_{2} \mathrm{CH}\left(\mathrm{CH}_{3}\right)_{2}\right), 3.63$, $3.75\left(\mathrm{~s}, 3 \mathrm{H}, \mathrm{CO}_{2} \mathrm{CH}_{3}, E / Z=1: 1.8\right), 4.20-4.30(\mathrm{~m},<$ $1 \mathrm{H}, \mathrm{CH}(\mathrm{NH}), E), 4.50-4.60(\mathrm{~m},<1 \mathrm{H}, \mathrm{CH}(\mathrm{NH}), Z)$, 5.70 (br, NH). ${ }^{13} \mathrm{C}-\mathrm{NMR}\left(\mathrm{CDCl}_{3}, 62.5 \mathrm{MHz}\right): \delta 13.8$ 
$\left(\mathrm{C} 2-\mathrm{CH}_{3}\right), 21.8,22.3,22.4,22.9,24.7,25.0,26.2,26.4$, 34.2, 34.4 (cyclohexyl- $\mathrm{CH}_{2},{ }^{i} \mathrm{Pr}-\mathrm{CH}_{2}, \mathrm{CH}_{3}$ ), 42.5, 44.1 $\left({ }^{i} \mathrm{Pr}-\mathrm{CHCH}_{2}\right)$, 51.8, $52.8\left(\mathrm{CO}_{2} \mathrm{CH}_{3}, E / Z\right), 53.2,55.0$ $(\mathrm{CH}(\mathrm{NH}), E / Z), 63.5(\mathrm{C} 4), 148.7$ (C3), 171.4, 171.9 $\left(\mathrm{CO}_{2} \mathrm{CH}_{3}, E / Z\right), 177.1 \quad(\mathrm{C} 2), 219.1$ (cis-CO), 226.4 (trans-CO), $304.9(\mathrm{C} 1)$. UV-vis $\left(\lambda_{\max }, \mathrm{nm}(\log \varepsilon)\right.$ [solvent]): 422 (4.297) $\left[\mathrm{CH}_{2} \mathrm{Cl}_{2}\right] ; 402$ (4.142) [DMF]. MS (140 $\left.{ }^{\circ} \mathrm{C}\right): m / z(\%): 469(15)\left[\mathrm{M}^{+}\right], 413(3)\left[\mathrm{M}^{+}-2 \mathrm{CO}\right]$, 385 (2) $\left[\mathrm{M}^{+}-3 \mathrm{CO}\right], 357$ (25) $\left[\mathrm{M}^{+}-4 \mathrm{CO}\right], 329$ (100) $\left[\mathrm{M}^{+}-5 \mathrm{CO}\right], 297$ (12) $\left[\mathrm{M}^{+}-5 \mathrm{CO}-\mathrm{CH}_{4} \mathrm{O}\right], 52$ (53) $\left[\mathrm{Cr}^{+}\right]$. Anal. Found: C, 56.43; H, 5.92; N, 3.05 . $\mathrm{C}_{22} \mathrm{H}_{27} \mathrm{CrNO}_{7}$ (469.46). Calc.: C, 56.29; H, 5.80; N, $2.98 \%$.

\subsubsection{Pentacarbonyl(3-N-(S)-leucinyl}

methylester-2,4,4-trimethyl-cyclobut-2-en-1-ylidene)chromium (10b)

Yellow crystals. Yield $0.24 \mathrm{~g}(92 \%$ relative to $\mathbf{3 b})$. M.p. $74^{\circ} \mathrm{C}$. IR $\left(\mathrm{CH}_{2} \mathrm{Cl}_{2}\right): v(\mathrm{CO})\left(\mathrm{cm}^{-1}\right): 2044 \mathrm{~m}, 1961$ vw, 1923 vs, br. ${ }^{1} \mathrm{H}-\mathrm{NMR}\left(\mathrm{CDCl}_{3}, 250 \mathrm{MHz}, \mathrm{TMS}\right): \delta$ $0.89,0.90,0.92,0.95,0.96,1.27,1.28,1.38\left(14 \mathrm{H}, \mathrm{CH}_{2}\right.$ and $\left.\mathrm{CH}_{3}\right), 1.50-1.75\left(\mathrm{~m}, 1 \mathrm{H}, \mathrm{CH}_{2} \mathrm{CH}\left(\mathrm{CH}_{3}\right)_{2}\right), 1.92$, $2.08\left(3 \mathrm{H}, \mathrm{CH}_{2}\right.$ and $\left.\mathrm{CH}_{3}\right), 3.75,3.78\left(s, 3 \mathrm{H}, \mathrm{CO}_{2} \mathrm{CH}_{3}\right.$, $E / Z=2: 1), 3.92-4.08(\mathrm{~m},<1 \mathrm{H}, \mathrm{CH}(\mathrm{NH})-E), 4.19-$ $4.32(\mathrm{~m},<1 \mathrm{H}, \mathrm{CH}(\mathrm{NH})-Z), 5.35-5.50(\mathrm{~m}, 1 \mathrm{H}, \mathrm{NH})$. ${ }^{13} \mathrm{C}-\mathrm{NMR}\left(\mathrm{CDCl}_{3}, 62.5 \mathrm{MHz}\right): \delta 11.2,13.6,19.5,22.2$, 22.4, 23.3, 23.5, 24.1, 24.8, $24.9\left(\mathrm{CH}_{2}, \mathrm{CH}_{3}\right), 42.6$ $\left(\mathrm{CH}_{2} \mathrm{CH}\left(\mathrm{CH}_{3}\right)_{2}\right), 53.1,53.2\left(\mathrm{CO}_{2} \mathrm{CH}_{3}, \mathrm{E} / \mathrm{Z}\right), 55.0,55.4$ $(\mathrm{CH}(\mathrm{NH}), E / Z), 58.9,59.7(\mathrm{C} 4, E / Z), 147.6,149.4(\mathrm{C} 3$, $E / Z), 171.3,171.4,171.9,174.5\left(\mathrm{C} 2, E / Z ; \mathrm{CO}_{2} \mathrm{CH}_{3}\right.$, $E / Z), 219.0,291.1$ (cis-CO, E/Z), 226.6 (trans-CO), $308.6(\mathrm{C} 1)$. UV-vis $\left(\lambda_{\max }, \mathrm{nm}(\log \varepsilon)\right.$ [solvent]): 422 (4.329) $\left[\mathrm{CH}_{2} \mathrm{Cl}_{2}\right] . \mathrm{MS}\left(160^{\circ} \mathrm{C}\right) \mathrm{m} / z(\%): 429(15)\left[\mathrm{M}^{+}\right]$, 373 (5) $\left[\mathrm{M}^{+}-2 \mathrm{CO}\right], 345$ (3) $\left[\mathrm{M}^{+}-3 \mathrm{CO}\right], 317$ (29) $\left[\mathrm{M}^{+}-4 \mathrm{CO}\right], 289(100)\left[\mathrm{M}^{+}-5 \mathrm{CO}\right], 257(10)\left[\mathrm{M}^{+}-\right.$ $\left.5 \mathrm{CO}-\mathrm{CH}_{4} \mathrm{O}\right], 231(10)\left[\mathrm{M}^{+}-5 \mathrm{CO}-\mathrm{C}_{2} \mathrm{H}_{2} \mathrm{O}_{2}\right], 52$ (45) $\left[\mathrm{Cr}^{+}\right]$. Anal. Found: C, 53.19; H, 5.29; N, 3.33. $\mathrm{C}_{18} \mathrm{H}_{23} \mathrm{CrNO}_{7}$ (429.4). Calc.: C, 53.15; H, 5.40; N, $3.26 \%$.

\subsubsection{Pentacarbonyl(2-methyl-3-N-(S)-phenylalaninyl} methylester-spiro[3.5]cyclobut-2-en-1-ylidene)chromium (12a)

Yellow powder. Yield $0.23 \mathrm{~g}(90 \%$ relative to $\mathbf{3 a})$. M.p. $61^{\circ} \mathrm{C}$. IR $\left(\mathrm{CH}_{2} \mathrm{Cl}_{2}\right) v(\mathrm{CO})\left(\mathrm{cm}^{-1}\right): 2045 \mathrm{w}, 1965$ vw, 1921 vs, 1917 s. ${ }^{1} \mathrm{H}-\mathrm{NMR}\left(\mathrm{CDCl}_{3}, 600 \mathrm{MHz}\right.$, TMS): $\delta 0.81-1.11,1.13-1.84,1.92-2.12(\mathrm{~m}, 10 \mathrm{H}$, ${ }^{\mathrm{c}} \mathrm{Hex}-\mathrm{CH}_{2}$ ), 1.92 (s, 3H, C2- $\left.\mathrm{CH}_{3}\right), 3.10,3.13,3.14,3.16$ (dd, $\left.2 \mathrm{H}, \mathrm{CH}_{2} \mathrm{Ph}\right), 3.81$ (s, 3H, $\left.\mathrm{CO}_{2} \mathrm{CH}_{3}\right), 4.41-4.49$ (m, $1 \mathrm{H}, \mathrm{CH}(\mathrm{NH})), 5.63-5.66(\mathrm{br}, \mathrm{NH}), 6.99-7.03(\mathrm{~m}, 2 \mathrm{H}$, phenyl), 7.19-7.29 (m, 3H, phenyl). ${ }^{13} \mathrm{C}-\mathrm{NMR}\left(\mathrm{CDCl}_{3}\right.$, $150.92 \mathrm{MHz}): \delta$ 13.7, $\left(\mathrm{C} 2-\mathrm{CH}_{3}\right), 25.0,26.3,34.2,34.4$

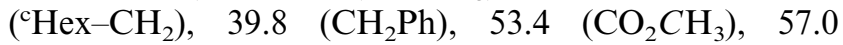
$(\mathrm{CH}(\mathrm{NH})), \quad 63.3$ (C4), 128.3, 129.2, 129.3, 133.4 (phenyl), 148.7 (C3), 170.3, $171.1\left(\mathrm{C} 2, \mathrm{CO}_{2} \mathrm{CH}_{3}\right), 219.1$ (cis-CO), 226.5 (trans-CO), 306.0 (C1). UV-vis $\left(\lambda_{\max }\right.$, nm $(\log \varepsilon)$ [solvent]): $422(4.255)\left[\mathrm{CH}_{2} \mathrm{Cl}_{2}\right] . \mathrm{MS}\left(200^{\circ} \mathrm{C}\right)$ : $m / z(\%): 503$ (10) $\left[\mathrm{M}^{+}\right], 447$ (3) $\left[\mathrm{M}^{+}-2 \mathrm{CO}\right], 391$ (14) $\left[\mathrm{M}^{+}-4 \mathrm{CO}\right], 363(63)\left[\mathrm{M}^{+}-5 \mathrm{CO}\right], 331(40)\left[\mathrm{M}^{+}-\right.$ $\left.5 \mathrm{CO}-\mathrm{CH}_{4} \mathrm{O}\right], 311(35)\left[\mathrm{M}^{+}-5 \mathrm{CO}-\mathrm{C}_{4} \mathrm{H}_{4}\right], 52$ (100) $\left[\mathrm{Cr}^{+}\right]$. Anal. Found: C, 58.71; H, 5.05; N, 2.89. $\mathrm{C}_{25} \mathrm{H}_{25} \mathrm{CrNO}_{7}$ (429.4). Calc.: C, 59.64; H, 5.00; N, $2.78 \%$.

3.6.4. Pentacarbonyl(2,4,4-trimethyl-3-N-(S)-

phenylalaninyl methylester-cyclobut-2-en-1-

ylidene)chromium (12b)

Orange-yellow sticky oil. Yield 0.25 g (92\% relative to 3b). IR $\left(\mathrm{CH}_{2} \mathrm{Cl}_{2}\right) v(\mathrm{CO})\left(\mathrm{cm}^{-1}\right) 2045 \mathrm{~m}, 1965 \mathrm{vw}$, 1921 vs, 1917 s. ${ }^{1} \mathrm{H}-\mathrm{NMR}\left(\mathrm{CDCl}_{3}, 600 \mathrm{MHz}, 243 \mathrm{~K}\right.$, TMS): $\delta 1.15,1.21,1.22,1.26\left(\mathrm{~s}, 6 \mathrm{H}, \mathrm{C} 4-\mathrm{CH}_{3}\right), 1.88(\mathrm{~s}$, $\left.3 \mathrm{H}, \mathrm{C} 2-\mathrm{CH}_{3}\right), 3.09-3.14\left(\mathrm{~m}, 2 \mathrm{H}, \mathrm{CH}_{2}-\mathrm{Ph}\right), 374,3.80$ (s, $\left.3 \mathrm{H}, \mathrm{CO}_{2} \mathrm{CH}_{3}, E / Z=3: 1\right), 4.10-4.25(\mathrm{~m},<1 \mathrm{H}$, $\left.\mathrm{CH}(\mathrm{NH}) \mathrm{CO}_{2}\left(\mathrm{CH}_{3} \mathrm{Bn}\right)-E\right), \quad 4.33-4.47 \quad(\mathrm{~m}, \quad<1 \mathrm{H}$, $\left.\mathrm{CH}(\mathrm{NH}) \mathrm{CO}_{2}\left(\mathrm{CH}_{3} \mathrm{Bn}\right)-\mathrm{Z}\right), 5.45$ (br, d, NH), 6.98-7.07 (m, 2H, Ph), 7.24-7.27 (m, 3H, Ph). ${ }^{13} \mathrm{C}-\mathrm{NMR}\left(\mathrm{CDCl}_{3}\right.$, $150.92 \mathrm{MHz}): \delta$ 13.4, 23.2, $23.6\left(\mathrm{C} 2-\mathrm{CH}_{3}, \mathrm{C} 4-\mathrm{CH}_{3}\right)$, $40.0(\mathrm{CH}-\mathrm{Bn}), 53.3\left(\mathrm{CO}_{2} \mathrm{CH}_{3}\right), 56.8(\mathrm{CH}\{\mathrm{NH}\}), 58.9$ (C4), 128.2, 129.1, 129.4, 133.5 (phenyl), 147.7 (C3), $170.2\left(\mathrm{CO}_{2} \mathrm{CH}_{3}\right), 171.4$ (C2), 218.9 (cis-CO), 226.6 (trans-CO), $308.8(\mathrm{C} 1)$. UV-vis $\left(\lambda_{\max }, \mathrm{nm}(\log \varepsilon)\right.$ [solvent]): 422 (4.261) $\left[\mathrm{CH}_{2} \mathrm{Cl}_{2}\right]$. MS $\left(160^{\circ} \mathrm{C}\right): \mathrm{m} / z(\%): 463$ (25) $\left[\mathrm{M}^{+}\right], 407(8)\left[\mathrm{M}^{+}-2 \mathrm{CO}\right], 351$ (42) $\left[\mathrm{M}^{+}-4 \mathrm{CO}\right]$, $323(85)\left[\mathrm{M}^{+}-5 \mathrm{CO}\right], 291(70)\left[\mathrm{M}^{+}-5 \mathrm{CO}-\mathrm{CH}_{4} \mathrm{O}\right]$, 232 (63) $\left[\mathrm{M}^{+}-5 \mathrm{CO}-\mathrm{CO}_{2} \mathrm{CH}_{3}\right], 121$ (20) $\left[\mathrm{BnCH}_{2} \mathrm{NH}_{3}^{+}\right]$, $91(20)\left[\mathrm{Bn}^{+}\right], 52(100)\left[\mathrm{Cr}^{+}\right]$. Anal. Found: C, 56.36; $\mathrm{H}$, 4.93; N, 3.07. $\mathrm{C}_{22} \mathrm{H}_{21} \mathrm{CrNO}_{7}$ (463.4). Calc.: C, 57.02; $\mathrm{H}, 4.57$; N, $3.02 \%$.

\subsubsection{Pentacarbonyl(3-N-(S)-methioninyl}

methylester-2-methyl-spiro[3.5]cyclobut-2-en-1-ylidene) chromium (14a)

Red-brown oil. Yield $0.21 \mathrm{~g}$ ( $82 \%$ relative to $\mathbf{3 a})$. IR $\left(\mathrm{CH}_{2} \mathrm{Cl}_{2}\right) v(\mathrm{CO})\left(\mathrm{cm}^{-1}\right): 2044 \mathrm{~m}, 1960 \mathrm{vw}, 1923 \mathrm{vs}$, 1917 s. ${ }^{1} \mathrm{H}-\mathrm{NMR}\left(\mathrm{CDCl}_{3}, 250 \mathrm{MHz}, \mathrm{TMS}\right): \delta 0.85-$ $0.93,1.08-1.34,1.74-1.92\left(\mathrm{~m}, 6 \mathrm{H},{ }^{\mathrm{c}} \mathrm{Hex}-\mathrm{CH}_{2}\right), 2.03$, $2.05,2.08\left(\mathrm{~s}, 6 \mathrm{H}, \mathrm{C} 2-\mathrm{CH}_{3}, \mathrm{SCH}_{3}\right), 2.12-2.17,2.48-$ $2.55\left(\mathrm{~m}, 3 \mathrm{H},{ }^{\mathrm{c}} \mathrm{Hex}-\mathrm{CH}_{2}, \mathrm{CH}_{2} \mathrm{CH}_{2} \mathrm{SCH}_{3}\right), 3.53(\mathrm{~m}, 2 \mathrm{H}$, $\mathrm{CH}_{2} \mathrm{SCH}_{3}$ ), 3.66, 3.80 (s, 3H, $\mathrm{CO}_{2} \mathrm{CH}_{3}, E / Z=4.1: 1$ ), 4.41-4.51 (m, <1H, CH(NH), E), 4.71-4.76 (m, < $1 \mathrm{H}, \mathrm{CH}(\mathrm{NH}), Z), 6.20$ (br, NH, E), 6.28 (br, NH, Z). ${ }^{13} \mathrm{C}-\mathrm{NMR}\left(\mathrm{CDCl}_{3}, 62.5 \mathrm{MHz}\right): \delta 13.8\left(\mathrm{C} 2-\mathrm{CH}_{3}\right), 15.4$, $15.6\left({ }^{i} \mathrm{Pr}-\mathrm{CH}_{3}\right), 22.3,25.0,26.2,29.5,30.5,31.7,33.9$, 34.3, 34.5 ( ${ }^{\mathrm{c}} \mathrm{Hex}-\mathrm{CH}_{2}, \mathrm{CH}_{2} \mathrm{CH}_{2} \mathrm{SCH}_{3}$ ), 52.1, 53.3, 53.4, $55.6\left(\mathrm{CO}_{2} \mathrm{CH}_{3}, \mathrm{CH}(\mathrm{NH}), E / Z\right), 63.7$ (C4), 148.9 (C3), $170.5,171.9\left(\mathrm{CO}_{2} \mathrm{CH}_{3}, E / Z\right), 176.1$ (C2), 219.1 (cisCO), 226.4 (trans-CO), $305.6(\mathrm{C} 1)$. UV-vis $\left(\lambda_{\max }, \mathrm{nm}\right.$ $(\log \varepsilon)$ [solvent]): 422 (3.980) $\left[\mathrm{CH}_{2} \mathrm{Cl}_{2}\right] \cdot \mathrm{MS}\left(250^{\circ} \mathrm{C}\right): \mathrm{m} / \mathrm{z}$ (\%): 487 (8) $\left[\mathrm{M}^{+}\right], 431$ (2) $\left[\mathrm{M}^{+}-2 \mathrm{CO}\right], 403$ (5) $\left[\mathrm{M}^{+}-\right.$

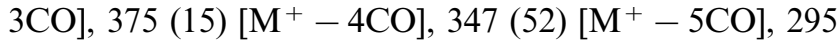
(50) $\left[\mathrm{M}^{+}-\mathrm{Cr}(\mathrm{CO})_{5}\right], \quad 221 \quad(45) \quad\left[\mathrm{M}^{+}-\mathrm{Cr}(\mathrm{CO})_{5}-\right.$ $\left.\mathrm{C}_{3} \mathrm{H}_{6} \mathrm{O}_{2}\right], 147$ (100) $\left[\mathrm{MeSCH}_{2} \mathrm{CH}_{2} \mathrm{CHCO}_{2} \mathrm{Me}^{+}\right.$], 87 (25) 


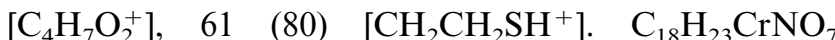
(429.4).

3.6.6. Pentacarbonyl(3-N-(S)-methioninyl methylester-2,4,4-trimethyl-cyclobut-2-en-1-ylidene)chromium (14b)

Red oil. Yield $0.23 \mathrm{~g}(85 \%$ relative to $3 \mathbf{b})$. IR $\left(\mathrm{CH}_{2} \mathrm{Cl}_{2}\right) v(\mathrm{CO})\left(\mathrm{cm}^{-1}\right): 2044 \mathrm{~m}, 1963 \mathrm{vw}, 1922 \mathrm{vs}$, 1918 sh. ${ }^{1} \mathrm{H}-\mathrm{NMR}\left(\mathrm{CDCl}_{3} / \mathrm{CS}_{2}, 250 \mathrm{MHz}, \mathrm{TMS}\right): \delta$ $1.28-2.53\left(\mathrm{~s} / \mathrm{m}, 14 \mathrm{H}, \mathrm{CH}_{3}, \mathrm{CH}_{2} \mathrm{CH}_{2} \mathrm{SCH}_{3}\right), 3.80(\mathrm{~s}, 3 \mathrm{H}$, $\left.\mathrm{CO}_{2} \mathrm{CH}_{3}, \quad \mathrm{~m}, 2 \mathrm{H}, \quad \mathrm{CH}_{2} \mathrm{CH}_{2} \mathrm{SCH}_{3}\right), 4.38(\mathrm{~m}, 1 \mathrm{H}$, $\mathrm{CH}(\mathrm{NH})), 6.11$ (br, $1 \mathrm{H}, \mathrm{NH}) .{ }^{13} \mathrm{C}-\mathrm{NMR}\left(\mathrm{CDCl}_{3} / \mathrm{CS}_{2}\right.$, $62.5 \mathrm{MHz}): \delta 11.3,13.5,15.6,22.3,23.4,23.6,24.0$, 24.8, 29.5, 29.8, $32.0\left(\mathrm{CH}_{2}, \mathrm{CH}_{3}\right), 53.4\left(\mathrm{CO}_{2} \mathrm{CH}_{3}\right)$, 55.1, $55.6(\mathrm{CH}(\mathrm{NH})-E / Z), 59.0,59.6,(\mathrm{C} 4-E / Z), 147.9(\mathrm{C} 3)$, 170.7, 172.2, $174.9\left(\mathrm{CO}_{2} \mathrm{CH}_{3}-E / Z, \mathrm{C} 2\right), 219.0$ (cis-CO), 226.8 (trans-CO), $307.9(\mathrm{C} 1)$. UV-vis $\left(\lambda_{\max }, \mathrm{nm}(\log \varepsilon)\right.$ [solvent]): $422(4.007)\left[\mathrm{CH}_{2} \mathrm{Cl}_{2}\right] . \mathrm{MS}\left(175^{\circ} \mathrm{C}\right) \mathrm{m} / z(\%)$ : 447 (20) $\left[\mathrm{M}^{+}\right], 363(10)\left[\mathrm{M}^{+}-3 \mathrm{CO}\right], 335$ (45) $\left[\mathrm{M}^{+}-\right.$ $4 \mathrm{CO}], \quad 307 \quad(97) \quad\left[\mathrm{M}^{+}-5 \mathrm{CO}\right], 292 \quad(25) \quad\left[\mathrm{M}^{+}-\right.$ $\left.5 \mathrm{CO}-\mathrm{CH}_{3}\right], \quad 264 \quad(20) \quad\left[\mathrm{M}^{+}-5 \mathrm{CO}-\mathrm{CO}\right], \quad 247 \quad$ (20) $\left[\mathrm{M}^{+}-5 \mathrm{CO}-\mathrm{C}_{2} \mathrm{H}_{4} \mathrm{O}_{2}\right], 52$ (100) $\left[\mathrm{Cr}^{+}\right] . \mathrm{C}_{18} \mathrm{H}_{21} \mathrm{CrNO}_{7} \mathrm{~S}$ (447.4).

\subsection{Reaction of $\mathbf{3} \boldsymbol{a}$ and $\mathbf{3} \boldsymbol{b}$ with cysteamine}

\subsubsection{Z-Pentacarbonyl[3-(2-mercaptoethyl)-} amino-2-methyl-spiro[3.5]-2-nonen-1-ylidene]chromium (Z-16a)

At $-40^{\circ} \mathrm{C}$, a solution of cysteamine $(0.39 \mathrm{mmol}, 30$ $\mathrm{mg}$ ) in $1 \mathrm{ml}$ of methanol is added to a solution of $\mathbf{3 a}$ $(0.24 \mathrm{mmol}, 0.09 \mathrm{~g})$ in $4 \mathrm{ml}$ of methanol. The solution is stirred at $-40^{\circ} \mathrm{C}$ for $10 \mathrm{~min}$ and then for another 25 $\min$ at $\mathrm{r}$.t. The solvent is removed in vacuo, the residue dissolved in $8 \mathrm{ml}$ of pentane-dichloromethane (3:1) and chromatographed at $-35^{\circ} \mathrm{C}$ with pentanedichloromethane (ratio decreasing from 1:0 to $1: 2$ ) on silica. The yellow band containing $Z$-16a is eluted. Removal of the solvent in vacuo and recrystallization from pentane-dichloromethane (1:1) affords $Z$-16a as a yellow powder. Yield $0.07 \mathrm{~g} \mathrm{(70 \%} \mathrm{relative} \mathrm{to} \mathrm{3a).} \mathrm{M.p.}$ $115^{\circ} \mathrm{C}$ (dec.). IR (pentane) $v(\mathrm{CO})\left(\mathrm{cm}^{-1}\right): 2047 \mathrm{~m}, 1962$ w, 1938 vs, 1920 s. ${ }^{1} \mathrm{H}-\mathrm{NMR}\left(\mathrm{CDCl}_{3}, 298 \mathrm{~K}, 250\right.$ MHz): $\delta 1.16-2.24\left(\mathrm{~m}, 10 \mathrm{H}, \mathrm{CH}_{2}\left(\mathrm{CH}_{2}\right)_{3} \mathrm{CH}_{2}\right), 1.45$ (t, $\left.7.2 \mathrm{~Hz}, 1 \mathrm{H}, \mathrm{CH}_{2} \mathrm{SH}\right), 2.18\left(\mathrm{~s}, 3 \mathrm{H}, 2-\mathrm{CH}_{3}\right), 2.87(\mathrm{~m}, 2 \mathrm{H}$, $\left.\mathrm{CH}_{2} \mathrm{SH}\right), 3.62\left(\mathrm{~m}, 2 \mathrm{H}, \mathrm{NCH}_{2}\right), 5.78(\mathrm{~s}$, br., $1 \mathrm{H}, \mathrm{NH})$. ${ }^{13} \mathrm{C}-\mathrm{NMR}\left(\mathrm{CDCl}_{3}, 273 \mathrm{~K}, 62.5 \mathrm{MHz}\right): \delta 14.0\left(2-\mathrm{CH}_{3}\right)$, $24.9\left(\mathrm{CH}_{2} \mathrm{SH}\right), 25.1$ (cHex-C-6, -C-8), 26.4 (cHex-C-7), 34.2 (cHex-C-5, -C-9), $46.1\left(\mathrm{NCH}_{2}\right), 63.0$ (C4), 149.0 (C3), 173.5 (C2), 219.2 (cis-CO), 226.7 (trans-CO), $301.6(\mathrm{C} 1)$. UV-vis $\left(\lambda_{\max }, \mathrm{nm}(\log \varepsilon)\right.$ [solvent]): 438 (3.520) [pentane], 396 (3.972) [DMF]. MS $m / z(\%)$ : 401(17) $\left[\mathrm{M}^{+}\right], 345(15)\left[\mathrm{M}^{+}-2 \mathrm{CO}\right], 289(25)\left[\mathrm{M}^{+}-\right.$ 4CO], 261(67) $\left[\mathrm{M}^{+}-5 \mathrm{CO}\right], 209(20)\left[\mathrm{M}^{+}-5 \mathrm{CO}-\mathrm{Cr}\right]$. Anal. Found: C, 50.74; H, 4.75; N, 3.40.
$\mathrm{C}_{17} \mathrm{H}_{19} \mathrm{CrNO}_{5} \mathrm{~S}$ (401.0). Calc.: C, 50.87; H, 4.77; N, $3.49 \%$

\subsubsection{E/Z-Pentacarbonyl[3-(2-mercaptoethyl)-}

amino-2,4,4-trimethylcyclobut-2-en-1-ylidene]chromium $(E / Z-16 b)$

At $-40^{\circ} \mathrm{C}$, a solution of cysteamine $(0.73 \mathrm{mmol}, 56$ $\mathrm{mg}$ ) of in $2 \mathrm{ml}$ of methanol is added to a solution of $3 \mathbf{b}(0.45 \mathrm{mmol}, 0.15 \mathrm{~g})$ in $8 \mathrm{ml}$ of methanol. The orange-red solution which immediately turns yellow is stirred at $-40^{\circ} \mathrm{C}$ for $30 \mathrm{~min}$. The solvent is removed in vacuo, the residue dissolved in $10 \mathrm{ml}$ of pentanedichloromethane $(2: 1)$ and chromatographed at $-35^{\circ} \mathrm{C}$ with pentane-dichloromethane/diethyl ether (ratio decreasing from 1:1:0 to 1:3:1) on silica. The yellow band is eluted. Removal of the solvent in vacuo affords $E / Z$-16b as a yellow, highly viscous oil. Yield $0.14 \mathrm{~g}$ ( $86 \%$ relative to $3 \mathbf{b})$. IR (pentane) $v(\mathrm{CO})\left(\mathrm{cm}^{-1}\right): 2048$ m, 1938 vs, 1923 s. ${ }^{1} \mathrm{H}-\mathrm{NMR}\left(\mathrm{CD}_{2} \mathrm{Cl}_{2}, 298 \mathrm{~K}, 250\right.$ MHz): $(Z) \delta 1.34\left(\mathrm{~s}, 6 \mathrm{H}, 4-\mathrm{CH}_{3}\right), 1.48(\mathrm{t}, J=8.7 \mathrm{~Hz}$, $1 \mathrm{H}, \mathrm{SH}), 2.17\left(\mathrm{~s}, 3 \mathrm{H}, 2-\mathrm{CH}_{3}\right), 2.86\left(\mathrm{~m}_{\mathrm{c}}, 2 \mathrm{H}, \mathrm{CH}_{2} \mathrm{SH}\right)$, $3.63\left(\mathrm{~m}_{\mathrm{c}}, 2 \mathrm{H}, \mathrm{NCH}_{2}\right), 5.50$ (s, br., $\left.1 \mathrm{H}, \mathrm{NH}\right) ;(E): \delta 1.43$ $\left(\mathrm{s}, 6 \mathrm{H}, 4-\mathrm{CH}_{3}\right), 1.53(\mathrm{t}, J=8.7 \mathrm{~Hz}, 1 \mathrm{H}, \mathrm{SH}), 1.99$ (s, $\left.3 \mathrm{H}, 2-\mathrm{CH}_{3}\right), 2.86\left(\mathrm{~m}_{\mathrm{c}}, 2 \mathrm{H}, \mathrm{CH}_{2} \mathrm{SH}\right), 3.48\left(\mathrm{~m}_{\mathrm{c}}, 2 \mathrm{H}\right.$, $\left.\mathrm{NCH}_{2}\right), 5.63$ (s, br., $\left.1 \mathrm{H}, \mathrm{NH}\right) .(E / Z=56: 44) .{ }^{13} \mathrm{C}-\mathrm{NMR}$ $\left(\mathrm{CDCl}_{3}, 273 \mathrm{~K}, \mathrm{JMODXH}\right):(Z): \delta 13.8\left(-, 2-\mathrm{CH}_{3}\right)$, 23.6, $24.4\left(-, 4-\mathrm{CH}_{3}\right), 25.0\left(+, \mathrm{CH}_{2} \mathrm{SH}\right), 46.1(+$, $\left.\mathrm{NCH}_{2}\right), 58.6(+, \mathrm{C} 4), 147.9(+, \mathrm{C} 2), 173.5(+, \mathrm{C} 3)$, $219.2(+$, cis-CO), $227.0(+$, trans $-\mathrm{CO}), 303.6(+$, $\mathrm{C} 1) ;(E) \delta=11.3\left(-, 2-\mathrm{CH}_{3}\right), 23.6,24.4\left(-, 4-\mathrm{CH}_{3}\right)$, $24.8\left(+, \mathrm{CH}_{2} \mathrm{SH}\right), 46.3\left(+, \mathrm{NCH}_{2}\right), 59.2(+, \mathrm{C} 4)$, $149.1(+, \mathrm{C} 2), 175.6(+, \mathrm{C} 3), 219.1(+$, cis $-\mathrm{CO})$, $227.0(+$, trans $-\mathrm{CO}), 301.1(+, \mathrm{C} 1) . \mathrm{UV}-\mathrm{vis}\left(\lambda_{\max }, \mathrm{nm}\right.$ $(\log \varepsilon)$ [solvent]): 438 (3.849) [pentane], 394 (3.892) [DMF]. MS $m / z(\%) ; 361(23)\left[\mathrm{M}^{+}\right]$, 305(11) $\left[\mathrm{M}^{+}-\right.$ $\mathrm{CO}], \quad 277(8) \quad\left[\mathrm{M}^{+}-3 \mathrm{CO}\right], 249(44) \quad\left[\mathrm{M}^{+}-4 \mathrm{CO}\right]$, 221(100) $\left[\mathrm{M}^{+}-5 \mathrm{CO}\right], 159(97)\left[\mathrm{M}^{+}-5 \mathrm{CO}-\mathrm{CH}_{3} \mathrm{CH}_{2-}\right.$ $\mathrm{SH}$. Anal. Found: C,47.74; H, 4.51; N, 3.91. $\mathrm{C}_{14} \mathrm{H}_{15} \mathrm{CrNO}_{5} \mathrm{~S} 1 / 8 \mathrm{C}_{5} \mathrm{H}_{12}$ (370.1), Calc.: C, 47.43; H, $4.49 ; \mathrm{N}, 3.78 \%$.

\subsubsection{E/Z-Pentacarbonyl[3-(2-mercaptoethyl)-} amino-2-methyl-4,4-diphenylcyclobut-2-en-1-yliden]chrom $(E / Z-16 c)$

At $-40^{\circ} \mathrm{C}$, a solution of cysteamine $(0.54 \mathrm{mmol}, 43$ $\mathrm{mg}$ ) in $1.5 \mathrm{ml}$ of methanol is added to a solution of $\mathbf{3 c}$ $(0.33 \mathrm{mmol}, 0.15 \mathrm{~g})$ in $6 \mathrm{ml}$ of methanol. The solution is stirred for $15 \mathrm{~min}$ at $-40^{\circ} \mathrm{C}$ and then for another 15 min at r.t. The solvent is removed in vacuo, the residue dissolved in $3 \mathrm{ml}$ of dichloromethane and chromatographed at $-35^{\circ} \mathrm{C}$ with pentanedichloromethane (ratio decreasing from $2: 1$ to $0: 1$ ) on silica. The second yellow band is eluted. Removal of the solvent in vacuo gives $E / Z-16 c$ as an orange, highly viscous oil. Yield $0.11 \mathrm{~g}(73 \%$ relative to $3 \mathbf{c})$. IR $\left(\mathrm{CH}_{2} \mathrm{Cl}_{2}\right) v(\mathrm{CO})\left(\mathrm{cm}^{-1}\right) ; 2046 \mathrm{~m}, 1968 \mathrm{w}, 1924$ vs. 
${ }^{1} \mathrm{H}-\mathrm{NMR}\left(\mathrm{CD}_{2} \mathrm{Cl}_{2}, 298 \mathrm{~K}, 250 \mathrm{MHz}\right):(E) \delta 1.18(\mathrm{t}$, $J=8.7 \mathrm{~Hz}, 1 \mathrm{H}, \mathrm{SH}), 2.02\left(\mathrm{~m}_{\mathrm{c}}, 2 \mathrm{H}, \mathrm{CH}_{2} \mathrm{SH}\right), 2.21(\mathrm{~s}, 3 \mathrm{H}$, 2- $\left.\mathrm{CH}_{3}\right), 3.19\left(\mathrm{~m}_{\mathrm{c}}, \mathrm{NCH}_{2}\right), 5.85$ (t, br., $\left.1 \mathrm{H}, \mathrm{NH}\right), 7.31-$ $7.55(\mathrm{~m}, 10 \mathrm{H}, \mathrm{Ph}) ;(Z) \delta=1.35(\mathrm{t}, J=8.7 \mathrm{~Hz}, 1 \mathrm{H}, \mathrm{SH})$, $2.38\left(\mathrm{~s}, 3 \mathrm{H}, 2-\mathrm{CH}_{3}\right), 2.76\left(\mathrm{~m}_{\mathrm{c}}, 2 \mathrm{H}, \mathrm{CH}_{2} \mathrm{SH}\right), 3.62\left(\mathrm{~m}_{\mathrm{c}}\right.$, $\left.\mathrm{NCH}_{2}\right), 5.54$ (t, br., 1H, NH), 7.31-7.55 (m, 10H, Ph). $(E / Z=60: 40) .{ }^{13} \mathrm{C}-\mathrm{NMR}\left(\mathrm{CDCl}_{3}, 273 \mathrm{~K}, 150.92 \mathrm{MHz}\right)$ : (E): $\delta 11.8\left(2-\mathrm{CH}_{3}\right), 23.8\left(\mathrm{CH}_{2} \mathrm{SH}\right), 46.8\left(\mathrm{NCH}_{2}\right), 73.3$ (C4), 128.0, 128.8, 129.5, $140.1(\mathrm{Ph}), 154.0(\mathrm{C} 2), 170.2$ (C3), 218.7 (cis-CO), 226.6 (trans-CO), 297.6 (C1); (Z): $\delta 14.4\left(2-\mathrm{CH}_{3}\right), 25.2\left(\mathrm{CH}_{2} \mathrm{SH}\right), 46.9\left(\mathrm{NCH}_{2}\right), 72.6(\mathrm{C} 4)$, 127.9, 129,0, 129.5, $140.8(\mathrm{Ph}), 153.0(\mathrm{C} 2), 169.2(\mathrm{C} 3)$, 218.6 (cis-CO), 226.4 (trans-CO), 301.8 (C1). UV-vis $\left(\lambda_{\max }, \mathrm{nm} \quad(\log \varepsilon)\right.$ [solvent]): 458 (3.931) [pentane], 412(4.150) [DMF]. MS $m / z(\%): 485(1)\left[\mathrm{M}^{+}\right] .373(2)$ $\left[\mathrm{M}^{+}-4 \mathrm{CO}\right], 345(4) \quad\left[\mathrm{M}^{+}-5 \mathrm{CO}\right], 293(100)\left[\mathrm{M}^{+}-\right.$ $5 \mathrm{CO}-\mathrm{Cr}], 278(42) \quad\left[\mathrm{M}^{+}-5 \mathrm{CO}-\mathrm{Cr}-\mathrm{CH}_{3}\right]$. Anal. Found: $\mathrm{C}, 59.05 ; \mathrm{H}, 4.04 ; \mathrm{N}, 2.62 . \mathrm{C}_{24} \mathrm{H}_{19} \mathrm{CrNO}_{5} \mathrm{~S}$ (485.5). Calc.: C, 59.38; H, 3.94; N, 2.89\%.

\section{8. $X$-ray structural analysis of $E-10 b$}

$\mathrm{C}_{38} \mathrm{H}_{46} \mathrm{Cr}_{2} \mathrm{~N}_{2} \mathrm{O}_{14}$, molecular mass (858.77), crystal size $0.5 \times 0.5 \times 0.5 \mathrm{~mm}^{3}$ (obtained by recrystallization from pentane-dichloromethane); crystal system Monoclinic, space group $P 2_{1}, a=12.731(4) \AA, b=12.530(4) \AA$, $c=14.036(5) \AA, \beta=102.45(1)^{\circ} ; V=2186.4(13) \AA^{3}, Z=$ $2, D_{\text {calc }}=1.304 \mathrm{~g} \mathrm{~cm}^{-3}, F(000) 896$; Adaptive $\omega$ scan, $2 \theta$ range $4.4-54.0^{\circ}$, scan rate variable $4.0-30.0^{\circ} \mathrm{min}^{-1}$. in $\omega ; 4990$ independent reflections, 3901 reflection with $I>2 \sigma(I) ; 505$ refined parameters; $R=0.0451, w R_{2}=$ 0.0993 . Largest difference peak (hole): $+0.292(-0.226)$ e $\AA^{-3}$.

The measurement was performed at $-35^{\circ} \mathrm{C}$ with a crystal mounted in a glass capillary on a Siemens P4 diffractometer (graphite monochromator, $\mathrm{Mo}-\mathrm{K}_{\alpha}$ radiation, $\lambda=0.71073 \AA$ ). The structure was solved by direct methods using the SHELXTL PLUS (VMS) program package. The positions of the hydrogen atoms were calculated by assuming ideal geometry $\left(d_{\mathrm{C}-\mathrm{H}}=0.96 \AA\right)$, and their coordinates were refined together with those of the attached carbon atoms as a riding model. The positions of all other atoms were refined anisotropically by the full-matrix least-squares method. The crystal consisted of two independent molecules.

\section{Supplementary material}

Crystallographic data for the structural analysis have been deposited with the Cambridge Crystallographic Data Center, CCDC no. 147723 for complex E-10b. Copies of the data may be obtained free of charge from The Director, CCDC, 12 Union Road, Cambridge CB2 1EZ, UK (Fax: + 44-1223-336033; e-mail: deposit@, ccdc.cam.ac.uk or www.ccdc.cam.ac.uk

\section{Acknowledgements}

Support of these investigations by Deutsche Forschungsgemeinschaft and the Fonds der Chemischen Industrie is gratefully acknowledged.

\section{References}

[1] H. Fischer, O. Podschadly, A. Früh, C. Troll, R. Stumpf, A. Schlageter, Chem. Ber. 125 (1992) 2667.

[2] H. Fischer, H.P. Volkland, A. Früh, R. Stumpf, J. Organomet. Chem. 491 (1995) 267.

[3] H. Fischer, O. Podschadly, G. Roth, S. Herminghaus, S. Klewitz, J. Heck, S. Houbrechts, T. Meyer, J. Organomet. Chem. 541 (1997) 321.

[4] A. Davison, J.P. Solar, J. Organomet. Chem. 155 (1978) C8.

[5] N.Y. Kolobova, V.V. Skripkin, G.G. Alexandrov, Yu T. Struchkov, J. Organomet. Chem. 169 (1979) 293.

[6] B.E. Boland-Lussier, R.P. Hughes, Organometallics 1 (1982) 635.

[7] R.M. Bullock, J. Am. Chem. Soc. 109 (1987) 8087.

[8] W. Weng, T. Bartik, M.T. Johnson, A.M. Arif, J.A. Gladysz, Organometallics 14 (1995) 889.

[9] H. Fischer, F. Leroux, G. Roth, R. Stumpf, Organometallics 15 (1996) 3723.

[10] H. Fischer, C.C. Karl, G. Roth, Chem. Ber. 129 (1996) 615.

[11] K.H. Dötz, H. Fischer, P. Hofmann, F.R. Kreissl, U. Schubert, K. Weiss (Eds.), Transition Metal Carbene Complexes, Verlag Chemie, Weinheim, 1983

[12] F.H. Allen, O. Kennard, D.G. Watson, L. Brammer, A.G. Orpen, R. Taylor, J. Chem. Soc. Perkin Trans. 2 (1987) S1.

[13] L. Brandsma, Preparative acetylenic chemistry, in: Studies in Organic Chemistry, vol. 34, second ed., Elsevier, Amsterdam, 1988.

[14] C.W. Huffmann, J. Org. Chem. 23 (1958) 727.

[15] D. Enders, P. Fey, H. Kipphardt, Org. Prep. Proced. Int. 17 (1985) 1. 